\title{
НОВІТНІ ПІДХОДИ ДО КОРЕКЦІЇ БОЛЬОВОГО СИНДРОМУ У ХВОРИХ 3 ОБЛІТЕРУЮЧИМ АТЕРОСКЛЕРОЗОМ НИЖНІХ КІНЦІВОК, ЩО ПРООПЕРОВАНІ МЕТОДОМ ЕНДОВАСКУЛЯРНОЇ БАЛОНОПЛАСТИКИ
}

\author{
${ }^{1}$ ДУ «Національна медична академія післядипломної освіти ім. П.Л. Шупика», Київ, Україна \\ ${ }^{2}$ КЗ КОР «Київська обласна клінічна лікарня», Україна
}

\begin{abstract}
3 метою оптимізувати інтраопераційну анестезіологічну тактику, для знеболення було використано епідуральну аналгезію.

Матеріали і методи. 40 пацієнтів були рандомізовано розподілені на дві групи по 20 осіб. Хворим I групи проводилась аналгоседація, II групи - епідуральна анестезія.

Результати. Застосування епідуральної анестезії розчином 0,125\% бупівакаїну в об'ємі 30 мл 3 додавання 0,12 мг розчину бупренорфіну забезпечувало адекватний рівень як інтра-, так і післяопераційної аналгезії при балонопластиці облітеруючого атеросклерозу нижніх кінцівок.
\end{abstract}

КЛЮчОВІ СЛОВА: критична ішемія нижніх кінцівок, ендоваскуляна балонопластика, епідуральна анестезія, бупренорфін.

Атеросклероз судин - це системне хронічне захворювання, при якому холестерин відкладається на стінках судин. Цей процес супроводжується ендотеліальною дисфункцією та місцевою запальною реакцію. Локальним проявом атеросклерозу $є$ облітеруючий атеросклероз судин нижніх кінцівок (OAC).

Гемодинамічні прояви ОАС наявні у 15\% населення у віці понад 55 років та до 20\% у похилому віці. До фракторів ризику виникнення ОАС належать: вік понад 50 років, чоловіча стать, паління, діабет, надлишкова вага, малорухливий спосіб життя, надлишковий рівень холестерину, артеріальна гіпертензія, родинний анамнез [10]. Щорічне зростання захворюваності на ОАС пов'язане зі зменшенням населення, яке веде активний спосіб життя, та погіршанням екології.

Важкі форми хронічної ішемії нижніх кінцівок мають особливу клінічну значущість. Так, при їх прогресуванні збільшується частота виникнення ішемічної хвороби серця на 54-57\%, гіпертонічної хвороби - на 70-75\%, порушень мозкового кровообігу - на 20-22\% [4].
Найбільш застосованою є клінічна класифрікація за Фонтейном-Покровським (табл. 1). Так, пацієнти 3 І стадією зазвичай навіть рідко звертаються до лікаря. Найбільш розповсюдженою є II стадія «переміжна кульгавість», - однак клінічний інтерес для лікаря-анестезіолога становлять III та IV стадії. Вони характеризують так звану «критичну ішемію кінцівок» (KI). Наявність виразок та постійного болю у спокої є одними з основних симптомів цього стану. Біль посилюється у горизонтальному положенні, при русі та у нічний час. Звичайні схеми призначення анальгетиків найчастіше $€$ неефективними, що призводить до підвищення їх дозування та призначення наркотичних препаратів [2].

Критична ішемія кінцівок виникає після хронічної нестачі кровопостачання кінцівки та тягне за собою низку патофрізіологічних процесів, що призводять до болю у спокої та виникнення трофічних виразок. Основні патологічні зміни можливо поділити на макро- та мікросудинні. До основних макросудинних змін відносять: артеріосклероз, атеросклероз, вазомоторний парез, зміни артеріального кровотоку, зменшення поперечного перерізу

Таблиця 1. Класифрікація облітеруючих захворювань артерій нижніх кінцівок за Фонтейном-Покровським

\begin{tabular}{|c|l|l|}
\hline Стадія & \multicolumn{1}{|c|}{ Назва } & \multicolumn{1}{c|}{ Клінічна картина } \\
\hline I & Первинні прояви & $\begin{array}{l}\text { Блідість кінцівок, мерзлякуватість, порушення чутливості, підвищене } \\
\text { потовиділення }\end{array}$ \\
\hline II & Переміжна кульгавість & $\begin{array}{l}\text { Поява болю при ходьбі від 200 м (стадія II а). } \\
\text { Поява болю при ходьбі менш ніж 200 м (стадія II б) }\end{array}$ \\
\hline III & Болі у спокої & Больовий синдром у нічні години, поява болю при ходьбі менш ніж 50 м \\
\hline IV & Поява виразок & Потужний больовий синдром, поява виразок \\
\hline
\end{tabular}

( Д.О. Дзюба, С.В. Верещагін, 2015 
судин, стоншення судинної стінки та порушення перфузії шкіри. До мікросудинних змін відносять: зниження рівня оксиду азоту, збільшення активних форм кисню, рівня продукції пероксинітриту, адгезії лейкоцитів, активацію тромбоцитів та мікросудинного тромбозу, колабування прекапілярних артеріол, порушення обміну кисню та набряк [18]. Внаслідок того, що пацієнти часто тримають кінцівку у вимушеному положенні, щоб полегшити біль у спокої, виникає подальше порушення вазомоторних реакцій та ще більше загострення набряку. Це збільшує гідростатичний тиск у дистальній частині кінцівки та негативно впливає на вже порушений кровотік. Усі ці зміни призводять до травмування ендотелію та реактивної гіперемії [7].

Патогенез ОАС та KІ зумовлює комплексний підхід до лікування даної патології, як методами консервативної терапії, так і хірургічним шляхом реваскулярізації чи, у найважчих випадках, ампутації пошкодженої кінцівки.

На жаль, не всі пацієнти, яким показано хірургічне лікування, мають змогу його отримувати через супутню патологію. У таких пацієнтів на перший план виходить консервативна терапія. Серед усіх методик основну частку у такої категорії хворих складають статини, антитромботичні та антигіпертензивні препарати. Дуже складно робити висновки щодо еорективності даних методик через неоднорідність методології досліджень, що проводились. Одним 3 найбільш вагомих $з$ точки зору доказової медицини є дослідження Schanzer та співавт., яке включало однорідну когорту пацієнтів. Статини приймали 45\% хворих, $\beta$-блокатори - 59\%, антитромботичну терапію - 80\%. Серед цих стратегій тільки терапія статинами показала статистичний вплив на виживаність пацієнтів з КІ [9; 15].

Велику кількість плацебоконтрольованих досліджень було присвячено вивченню ефектів аналогів простацикліну, але не показано їхньої ефективності [5; 12; 14].

Серед питань консервативної терапії особливу увагу лікаря-анестезіолога привертає лікування больового синдрому. На даний час одним 3 основних засобів керування болем у пацієнтів з КІ залишаються опіати. Але з їх використанням пов'язана низка побічних ефектів [6]. Передусім вони можуть викликати порушення психічної рівноваги та сприйняття оточуючого середовища у вигляді ейфрорії чи дисорорії, які викликані впливом на лімбічну систему. Іноді ці препарати викликають сонливість, однак повної втрати свідомості при використанні стандартних дозувань не виникає.

Ще одними 3 вагомих побічних ефектів опіатів $€$ пригнічення кашльового рефлексу та дихання. Депресія дихання - дозозалежний побічний еорект, зумовлений зниженням чутливості дихального центра до $\mathrm{CO}_{2}$, а дія на міст - зменшення частоти дихань. Усі опіоїди пригнічують кашльо- вий рефрлекс (деякі частково) через прямий вплив на кашльовий центр, що розташований в межах довгастого мозку. Залежності між ефектами пригнічення дихання та пригнічення кашлю не виявлено. Характерними $€$ гіпотонія та брадикардія, що зумовлено впливом препаратів на діяльність nucleus ambiguus стовбура та вагальні центри. Велика кількість опіатних рецепторів також міститься в афрерентних волокнах вагусу.

Найчастіше у рутинній практиці застосування опіатів зустрічаються ефекти на шлунковокишковий тракт, у якому міститься багато опіатних рецепторів, оскільки його ембріоґенез близький до ембріоґенезу ЦНС. Опіоїди загалом діють як інгібітори, пригнічують процес спорожнення шлунка, перистальтику, жовчоутворення й викликають спазм сорінктера Одді, що викликає у багатьох хворих нудоту та блювання.

Також опіати мають вплив на сечостатеву систему. Знижується функція нирок, імовірно через зменшення їх перфузії. Може збільшуватися виділення антидіуретичного гормона. Підвищується тонус сечоводів, сечового міхура, сфрінктера сечівника.

Не можна не згадати про те, що опіати збільшують викид гістаміну, що викликає почервоніння, свербіж шкіри і збільшення потовиділення [1].

Для лікування больового синдрому при КІ також використовують розчин кетаміну. Так, у подвійному плацебоконтрольованому дослідженні малих доз кетаміну показано його перевагу над опіатним знеболюванням $[11 ; 16]$. Кетамін має специфрічні побічні ефекти, такі як ейфорія, головний біль, ажитація, ністагм, нудота та блювання [1], однак ці прояви характерні для стандартних дозувань, а при застосуванні «субанестетичних» доз (0,15-0,5 мг/кг) вони співвідносні з побічними ефектами опіатів [8].

Лідокаїн, більш відомий як місцевий анестетик та препарат, що має певні кардіологічні еоректи, останнім часом привертає увагу лікаріванестезіологів через виявлені антианалгетичні есректи при внутрішньовенному застосуванні. Так, при лікуванні ішемічного больового синдрому розчин лідокаїну суттєво покращує терапію КІ [17].

Щодо хірургічних методів лікування КІ, то і методи ревасуляризації відкритим способом, і методи ендоскопічного відновлення прохідності артерій мають позитивній вплив на час збереження функціонування нижніх кінцівок. Дослідження останніх років показали, що методи едовасулярної пластики судин мають бути першим вибором при KI, а шунтування судин відкритими методами повинно застосовуватися у пацієнтів, що не мали позитивного ефректу від балонопластики [13].

Едоваскулярна ангіопластика, як і більшість методів лікування, має і негативні ефекти. До них можна віднести виникнення реперфузійного синдрому. Так, включення кровотоку ішемізованих ділянок нижніх кінцівок тільки збільшує ноцицеп- 
тивну стимуляцію. Реперфузійний синдром проявляється у вигляді посилення больового синдрому, післяопераційного набряку та збільшення зони трофрічних змін [19].

Мета роботи: оптимізувати інтраопераційну анестезіологічну тактику під час балонопластики судин нижніх кінцівок шляхом застосування епідуральної анестезії.

Матеріали і методи. У дослідження, що проводилося у Київській обласній клінічній лікарні, були включені 40 пацієнтів, які були рандомізовано розподілені на дві групи по 20 осіб. Усім хворим виконували в плановому порядку балонопластику судин нижніх кінцівок при КІ.

Пацієнтам I групи проводилась аналгоседація розчином френтанілу у дозі 1,5-2 мкг/кг/год та розчином сибазону у дозі 10 мг.

Пацієнтам II групи за 30 хвилин до оперативного втручання проводилась епідуральна анестезія на сакральному рівні розчином 0,125\% бупівакаїну в об'ємі 30 мл 3 додавання 0,12 мг розчину бупренорфіну.

У післяопераційному періоді усім хворим проводили рутинне знеболення кеторолаком у дозі 30 мг кожні 8 годин, а при виразному болю (при шБ >3 балів) додавали по 20 мг омнопону парентерально, але не частіше восьми годин між введеннями останнього.

Основні антропометричні та клініко-лабораторні характеристики хворих у групах були порівнянними.

Інтенсивність больового синдрому оцінювали за числовою рейтинговою шкалою болю (ШБ) від 0 до 10 балів.

Тонус симпатичної нервової системи оцінювали за такими показниками, як частота серцевих скорочень та рівні артеріального тиску.

Оцінку проводили: до операції, на початку операції, через 15 хвилин після початку операції, через годину після початку операції, після оперативного втручання через 1, 3, 8, 24 та 48 годин.

Результати дослідження та їх обговорення. У хворих контрольної групи рівень больового син- дрому за ШБ у часових проміжках через 15 хвилин та через годину після початку оперативного втручання був в середньому удвічі вищим, ніж у пацієнтів з епідуральними методами аналгезії. Слід зазначити, що інтраопераційно у 67\% хворих додатково вводився розчин фентанілу у дозі 1-1,5 мкг/кг.

На етапі після оперативного втручання рівень болю за ВАШ був у 2,3 разу вищим в контрольній групі, ніж в II дослідній групі.

Щодо показників систолічного, діастолічного тиску та чСС, то у хворих I групи показники були з тенденцією до гіпердинамії, як інтраопераційно, так і на 1, 3 та 8 годину раннього післяопераційного періоду.

У пацієнтів II групи максимальній рівень болю не перевищував трьох балів за ШБ, в той час як у контрольній максимальний рівень за ШБ сягав семи балів.

У післяопераційному періоді відчуття сильного болю (більше трьох балів за ШБ) не відмічали 95\% прооперованих II групи, у той час як у хворих I групи він з'являвся у 65\%, що свідчить про значний комфорт пацієнта в післяопераційному періоді.

Одним 3 показників якості післяопераційної аналгезії $€$ додаткове введення наркотичних анальгетиків «на вимогу» пацієнта. Так, у I групі опіоїди вводились додатково один раз у 55\% прооперованих, два рази - у 20\%, три рази - у $15 \%$, додатково не вводились - у 35\% хворих. Потреба в одноразовому введенні наркотичних анальгетиків була у 5\% прооперованих 3 епідуральним знеболюванням, що підтверджує якість запропонованого методу знеболення.

\section{Висновки}

Застосування епідуральної анестезії розчином 0,125\% бупівакаїну в об'ємі 30 мл 3 додавання 0,12 мг розчину бупренорфіну забезпечувало адекватний рівень як інтра-, так і післяопераційної аналгезії при балонопластиці облітеруючого атеросклерозу нижніх кінцівок.

\section{Список літератури}

1. Анестезіологія та інтенсивна терапія : підр. для лікарів-інтернів та слухачів вищих навчальних медичних закладів III-IV рівнів акредитації та закладів післядипломної освіти / за ред. профр. І. П. Шлапака. - Київ. : Ніка Прінт, 2013. $-550 \mathrm{c}$.

2. Лазарева М. А. Заболевания периферических артерий, артериол и капилляров : учебн. пособ. для амбулаторнополиклинических хирургов / М. А. Лазарева, А. Ю. Мацких, М. А. Лазарева. - Екатеринбург : уГМу, 2014. - 88 с.

3. Основные принципы диагностики и амбулаторного лечения облитерирующего атеросклероза артерий нижних конечностей / Кузнецов М. Р. [и др.] // РМЖ. - 2012. - Т. 20, № 36. - С. 1733-1737.

4. Савельев В. С. Критическая ишемия нижних конечностей / В. С. Савельев, В. М. Кошкин. - М., 1997. - 123 с.

5. A randomized, controlled pilot study of autologous CD34+ cell therapy for critical limb ischemia / Losordo D. W. [et al.] // Circulation: Cardiovascular Interventions. - 2012. - T. 5, № 6. - C. 821-830.

6. Chapter IV: treatment of critical limb ischaemia / Setacci C., de Donato G., Teraa M. [et al.] // Europian Journal of Vascular and Endovascular Surgrery. - 2011. -T. 42 (Suppl. 2). - C. 43-59.

7. Coats $P$. Marriage of resistance and conduit arteries breeds critical limb ischemia / P. Coats, R. Wadsworth // American Journal of Physiology-Heart and Circulatory Physiology. - 2005. - T. 288, №. 3. - C. H1044-H1050.

8. Comparison of intravenous lidocaine versus morphine in alleviating pain in patients with critical limb ischaemia / Vahidi E. [et al.] // Emergency medicine journal. - 2014. 
9. Heart Protection Study Collaborative Group et al. Randomized trial of the effects of cholesterol-lowering with simvastatin on peripheral vascular and other major vascular outcomes in 20,536 people with peripheral arterial disease and other high-risk conditions // Journal of Vascular Surgery. - 2007. - T. 45, №. 4. - C. 645-654.

10. Inter-society consensus for the management of peripheral arterial disease (TASC II) / Norgren L. [et al.] // European Journal of Vascular and Endovascular Surgery. - 2007. - T. 33, №. 1. - C. 1-75.

11. Low-dose ketamine vs morphine for acute pain in the ED: a randomized controlled trial / Miller J. P. [et al.] // The American journal of emergency medicine. - 2015. - T. 33, №. 3. - C. 402-408.

12. Parenteral therapy with lipo-ecraprost, a lipid-based formulation of a PGE1 analog, does not alter six-month outcomes in patients with critical leg ischemia / Brass E. P. [et al.] // Journal of vascular surgery. - 2006. - T. 43, № 4. - C. $752-759$.

13. Rapidly progressing fatal reperfusion syndrome caused by acute critical ischemia of the lower limb / Szijбrty A. [et al.] // Cardiovascular Pathology. - 2013. - T. 22, № 6. - C. 493-500.

14. Results of the randomized, placebo-controlled clopidogrel and acetylsalicylic acid in bypass surgery for peripheral arterial disease (CASPAR) trial / Belch J. J. F. [et al.] // Journal of vascular surgery. - 2010. - T. 52, №. 4. - C. 825-833.

15. Statins are independently associated with reduced mortality in patients undergoing infrainguinal bypass graft surgery for critical limb ischemia / Schanzer A. [et al.] // Journal of vascular surgery. - 2008. - T. 47, №. 4. - C. 774-781.

16. Tawfic $Q$. A. Ultra-low-dose ketamine infusion for ischemic limb pain / Q. A. Tawfic, N. Eipe, J. Penning // Canadian Journal of Anesthesia/Journal canadien d'anesthйsie. - 2014. - T. 61, № 1. - C. 86-87

17. The Clinical Relationship Between Body Mass Index And Mortality In Patients With Critical Limb Ischemia Undergoing Endovascular Treatment / Murata N. [et al.] // Journal of the American College of Cardiology. - 2014. - T. 63 , № 12.

18. Varu V. N. Critical limb ischemia / V. N. Varu, M. E. Hogg, M. R. Kibbe // Journal of vascular surgery. - 2010. - T. 51, №. 1. - C. 230-240.

\section{НОВЫЕ ПОДХОДЫ К КОРРЕКЦИИ БОЛЕВОГО СИНДРОМА У БОЛЬНЫХ С ОБЛИТЕРИРУЮ- ЩИМ АТЕРОСКЛЕРОЗОМ НИЖНИХ КОНЕЧНОСТЕЙ, КОТОРЫЕ ПРООПЕРИРОВАНЫ МЕТОДОМ ЭНДОВАСКУЛЯРНОЙ БАЛОНОПЛАСТИКИ}

Д.А. Дзюба ${ }^{1}$, С.В. Верещагин ${ }^{2}$

1ГУ «Национальная медицинская академия последипломного образования им. П.Л. Шупика», Киев, Украина

${ }^{2}$ КУ КОР «Киевская областная клиническая больница», Украина

С целью оптимизировать интраоперационную анестезиологическую тактику, для обезболивания использовали эпидуральную анестезию.

Материалы и методы. 40 пациентов были рандомизировано распределены на две группы по 20 человек. Больным I группы проводили аналгоседацию, группы - II эпидуральную аналгезию.

Результаты. Использование эпидуральной анестезии раствором 0,125\% бупивакаина в объеме 30 мл с добавлением 0,12 мг раствора бупренорфина обеспечивало адекватный уровень как интра-, так и послеоперационного обезболивания при балонопластике облитерирующего атеросклероза нижних конечностей.

КЛЮЧЕВЫЕ СЛОВА: критическая ишемия нижних конечностей, эндоваскулярная балонопластика, епидуральная аналгезия, бупренорфин.

\section{NEW APPROACHES OF PAIN MANAGEMENT OF PATIENTS WITH ATHEROSCLEROSIS OBLITERANS OF THE LOWER LIMBS, WHICH WAS OPERATED BY ENDOVASCULAR BALONPLASTICS}

D.A. Dziuba ${ }^{1}$, S.V. Vereshchagin ${ }^{2}$

${ }^{1}$ National Medical Academy of Postgraduate Education named after P.L.Shupik, Kyiv, Ukraine

${ }^{2}$ Kyiv Regional Hospital, Ukraine

Purpose. In order to optimize the intraoperative anesthesia tactics we used epidural anesthesia.

Materials and methods. There were 40 patients. They were randomized into 2 groups of 20 people. Patients of I group performed analgosedation, group - II epidural analgesia.

Results. The use of epidural anesthesia sol. $0.125 \%$ bupivacaine in the volume of $30 \mathrm{ml}$ with the addition of $0.12 \mathrm{mg}$ of sol. Buprenorphine provided adequate levels of both intra- and postoperative analgesia of balonplastics of obliterating atherosclerosis of the lower limbs.

KEY WORDS: critical ischemia of the lower limbs, endovascular balonplastics, epidural analgesia, Buprenorphine.

Відомості про авторів:

Рукопис надійшов до редакції 10.06.2015 р.

Дзюба Дмитро Олександрович - к.мед.н., ас. кафедри анестезіології та інтенсивної терапії Національної медичної академії післядипломної освіти ім. П.Л. Шупика. Адреса: 04112, м. Київ, вул. Дорогожицька, 9.

Верещагін С. В. - к.мед.н., завідувач відділення інтервенційної радіології КЗ КОР “Київська обласна клінічна лікарня". 